JEL: Q00, R11, R12, R51

Iryna Storonyanska ${ }^{1}$, Khrystyna Patytska ${ }^{1}$, Iryna Hrynchyshyn ${ }^{1}$, Vasyl Chemerys ${ }^{2}$

${ }^{I}$ State Institution «Institute of Regional Research named after M. I. Dolishniy of the NAS of Ukraine»

${ }^{2}$ Stepan Gzhytskyi National University of Veterinary Medicine and Biotechnologies Lviv

Ukraine

\title{
SPATIAL DISPROPORTIONS IN DEVELOPMENT OF TERRITORIAL COMMUNITY UNDER CONDITIONS OF ADMINISTRATIVE AND FINANCIAL DECENTRALIZATION
}

Purpose. The purpose of the article is to identify the spatial features of the social-economic development of territorial communities in the context of administrative and financial decentralization.

Methodology / approach. The method of system analysis is used in the work - to research the spheres of central-peripheral interactions at the level of territorial communities; method of comparative analysis - to identify trends in the formation and development of interactions between the center and the periphery in communities and the factors that determine them; abstract-logical method - for the formation of theoretical generalizations and formulation of conclusions from the research; method of graphic visualization, which allows providing a clear presentation of the results of the analysis; sociological survey of chairmen of local councils of territorial communities of Lviv region - to determine the state of development of central-peripheral interactions in their communities. The key role of territorial and systemic approaches to the analysis of core-peripheral interactions in territorial communities is emphasized, which made it expedient to form a research method based on taking into account the conditions for the development of a particular environment and existing spatial restrictions.

Results. The article identifies the features of the formation of core-peripheral interactions in the territorial communities of rural areas. It is focused on the formation of derivative coreperipheral interactions that arise in the territorial communities created during the implementation of administrative-territorial reform. On the basis of a systematic and comprehensive analysis, the existing and hidden core-peripheral dependencies were identified and the features of the mutual influence of the centers of the united territorial communities of the rural areas of the Lviv region on the socio-economic development of the community territory were revealed. The problems and risks of the development of the territory of the community are substantiated in the context of the mutual influence of a derivative nature.

Originality / scientific novelty. A scientific approach to the identification of centralperipheral interactions in territorial communities was developed, which allows identifying the spatial effects of social, economic, managerial interactions of the center and the periphery within the community. A scientific-and-methodological approach to the assessment of central-peripheral interactions was developed, which provides for the selection of community groups according to certain criteria (community type (town / township / village), community composition, location in the region) and their diagnosis in areas: analysis of strategic documents of local council on the development of central-peripheral interactions in a community; analysis of the management structure of the local council, representation of peripheral communities, compliance of the composition and structure of the governing body with the goals of community development; 
analysis of budget support for infrastructure development; research of employment opportunities in the community. The application of the approach will reveal the patterns of formation of centralperipheral interactions at the level of territorial communities.

Practical value / implications. The results of the study make it possible to have a more comprehensive assessment of the state of the formation of central-peripheral interactions in territorial communities, contribute to the identification of risks of social conflict between different groups in the community and to form recommendations for their activation. The results are recommended for consideration by local governments when preparing proposals for socioeconomic development and ensuring the financial capacity of local communities.

Key words: central-peripheral interactions, territorial community, local government, local budget, administrative and financial decentralization, Ukraine.

Introduction and review of literature. Among the key tasks under conditions of the reform of the administrative-territorial structure and financial decentralization is to reduce the level of spatial socio-economic imbalances in the development of territories and ensure the ubiquity of high quality of life of the population and the development of the business environment $[1 ; 2 ; 3]$. The formation of the organizational and economic foundations for the development of territorial communities, the transfer of powers and resources to the local level increase the responsibility of local governments for the rational use of endogenous potential and opportunities for inter-territorial cooperation in the context of solving common challenges of socio-economic development.

A necessary condition for the functioning and development of territorial communities formed by unification is the establishment of relationships and consideration of the mutual influences of the center and the periphery in the communities. This raises the question of central-peripheral interactions in the context of administrative and financial decentralization, requires the determination of the zones of influence of the centers and the peculiarities of activating the adaptive and stimulating roles that they perform as "growth poles" and generators of innovative upheavals in territorial development.

Existing studies of the interaction of the center and the periphery are mainly carried out in direction of studying the depression of territorial development, the labor market, educational and transport and logistics systems (M. J. Rhodes, R. Epstein, T. A. Börzel (2019) [4]; T. A. Börzel， J. Langbein (2019) [5]; I. U. Uwazie, A. A. Igwemma, F. I. Ukah (2015) [6]). At the same time, insufficient attention is paid to the financial and economic aspects of the influence of the "center" (core, growth point) on spatial, social, cultural development in the system of centerperipheral interactions. The issues of developing effective methodological approaches to the study of social, financial and economic, managerial relations between the center and its adjacent territory, in particular under the current conditions of administrative and financial decentralization, remain undeveloped.

In this context, the theory of new economic geography, formed in the scientific works by P. Krugman (1998) [7], is important, within the framework of which the peculiarities of the process of regional polarization as a result of the interaction of 
economies with different basic characteristics are justified. A. Ascani, R. Crescenzi, S. Iammarino (2012) [8] and H. Caraveli (2017) [9] note that economic integration between developed and underdeveloped territories has a direct impact on the spatial location of economic entities through access to markets. At the same time, in modern conditions, the study of core-peripheral interactions is reaching a new level, since today peripherality is determined not only by spatial arrangement. In the research by M. Naumann, A. Fischer-Tahir (2013) [10] the concept of "aspatial peripherality" appeared, in which the factors influencing the acquisition of the center or periphery features by the territory are the local information infrastructure and communications, social and human capital, local entrepreneurial networks, the inclusion of local entrepreneurs in civil society, institutional networks between economics and politics, and the integration of the local economy into the global market.

Thus, the scope of research of core-peripheral interactions has been expanded. In particular, S. Schulz (2020) [11] considers the issue of core-peripheral interaction in the context of the implementation of cohesian policies in the EU and the development of smart specialization, G. Magerman, K. De Bruyne, J. Van Hove (2020) [12] - from the side of influence on the development of international trade. P. Cohendet, D. Grandadam, C. Mehouachi, L. Simon (2018) [13] emphasize the need to harmonize the prospects for the development of international business in the context of economic geography, which will contribute to reconciliation between the current business dynamics and the spatial conditions of human potential development.

Studying the formation of core-peripheral interactions under conditions of the consolidation of territorial communities, it is necessary to emphasize the work by M. Bernt, L. Colini (2013) [14], who, next to the concept of peripherality, place the categories of "exclusion" and "marginalization", noting that socio-spatial inequality is growing not only at the inter-regional level, but also within territorial communities as well. The research by C. Nordlund (2018) [15] is significant, which emphasizes the role of government in the development of central-peripheral interactions, other existing approaches to the study do not cover such dependencies.

Comprehensive studies by B. Draçi, D. Çaro, P. Nikolli (2014) [16] regarding the interactions of the center and the periphery within the town, where the assessment of spatial development imbalances were carried out and the change of territorial space was determined, were aimed at the formation of effective methodological approaches to the analysis of the development of core-peripheral interactions. Also, noteworthy are the methods for assessing human capital in the context of remoteness from the centers of economic development, developed by J. Kubeš, A. Chvojková (2020) [17] and analysis of the potential of residents of peripheral areas to adapt to changing socio-economic conditions by G. Pociute-Sereikiene, E. Kriaučiunas (2018) [18].

Among Ukrainian scientists, O. Denysenko, K. Mezentsev, N. Mezentseva, M. Melnyk, I. Pylypenko, G. Pidgrushny, S. Schults and others study centralperipheral interactions. Thus, I. Pylypenko emphasizes the dual nature of central- 
peripheral interactions - topological, which he defines as primary (spatial differentiation of the place provides its hierarchy and order), and metric, which acquires a certain territory under the influence of demographic, socio-economic, infrastructural factors [18]. G. Pidgrushny and O. Denysenko identify the factors that stimulate the development of the center and ensure its impact on the periphery: the functioning of cities, which are characterized as powerful "markets for goods and services" and concentrate on their territory engineering, social, industrial infrastructure, resources and human capital; consolidation of the communicative space due to the strengthening of interpersonal ties, which results in the emergence of innovative effects; increase in the value of land, resources and real estate within the nuclei, which stimulates the effect of "pushing" certain types of production in the surrounding areas; dynamics of the social environment [20]. It should be noted that, analyzing the features of centro-peripheral interactions, most scientists emphasize the problem of peripheral perception of pulses from the center and point to the need to typify spatial zones by the difference in intensity of the main nucleus, highlighting areas of central, semi-peripheral and peripheral type [21;22].

Thus, based on the analysis of scientific approaches to the study of the interaction of center and periphery, the concept of "center-peripheral interactions" is defined as a process of direct or indirect interaction of center and periphery in terms of spatial inequality and socio-economic differentiation of territories, and results in a change in the dynamics of their development. The key features of the interaction of the center and the periphery are: 1) the difference in the intensity of the center's influence on the peripheral territories, which is due to the different ability of them to perceive the impulses of development from the center; 2) the dependence of the level of perception of the territory of the impulses generated by the center, from its internal potential to development; 3) the dynamics of the center and periphery, which determines their permanent transformation.

The purpose of the article is to identify the spatial features of the socialeconomic development of territorial communities in the context of administrative and financial decentralization.

Results and discussion. The issues of formation and development of coreperipheral interactions in the territorial communities (TC) requires special attention given the nature of their formation. The development of core-peripheral interactions in the region at the level of towns and their zones of influence has a natural character and is determined by the intensification of relationships and mutual influence in a certain functional space. In such a way, the reform of the administrative-territorial structure leads to a change in the directions of relationships in the territory of the formed administrative-territorial unit (Fig. 1).

Despite the fact that the process of formation of the local communities took place on a voluntary basis and took into account historical, natural, ethnic, cultural and other factors, the consolidation of communities could not avoid certain risks. In particular, in the first wave of unification (2015-2016) of TC, frequently it was formed due to the consolidation of 2-3 local councils, obviously unable to ensure the 
socio-economic development of the territory, which were formed to obtain financial resources from the state budget in the form of subventions for social-economic development of territories and the formation of TC infrastructure. Today, such TCs, in accordance with the Ordinances of the Cabinet of Ministers of Ukraine ${ }^{1}$, join large communities or enlarge as a result of the annexation of settlements to ensure the capacity of these territories. In spite of the positive assessment of this process, attention should be focused on the problem of insufficient study of core-peripheral interactions in such communities, in particular in terms of the interaction of a sociopsychological nature. Since, the liquidation of self-governing bodies of TCs, which, despite their financial insolvency, positively "proved" themselves to the population thanks to financial support from the state budget, may result in rejection and the emergence of social conflict in the newly formed TCs.

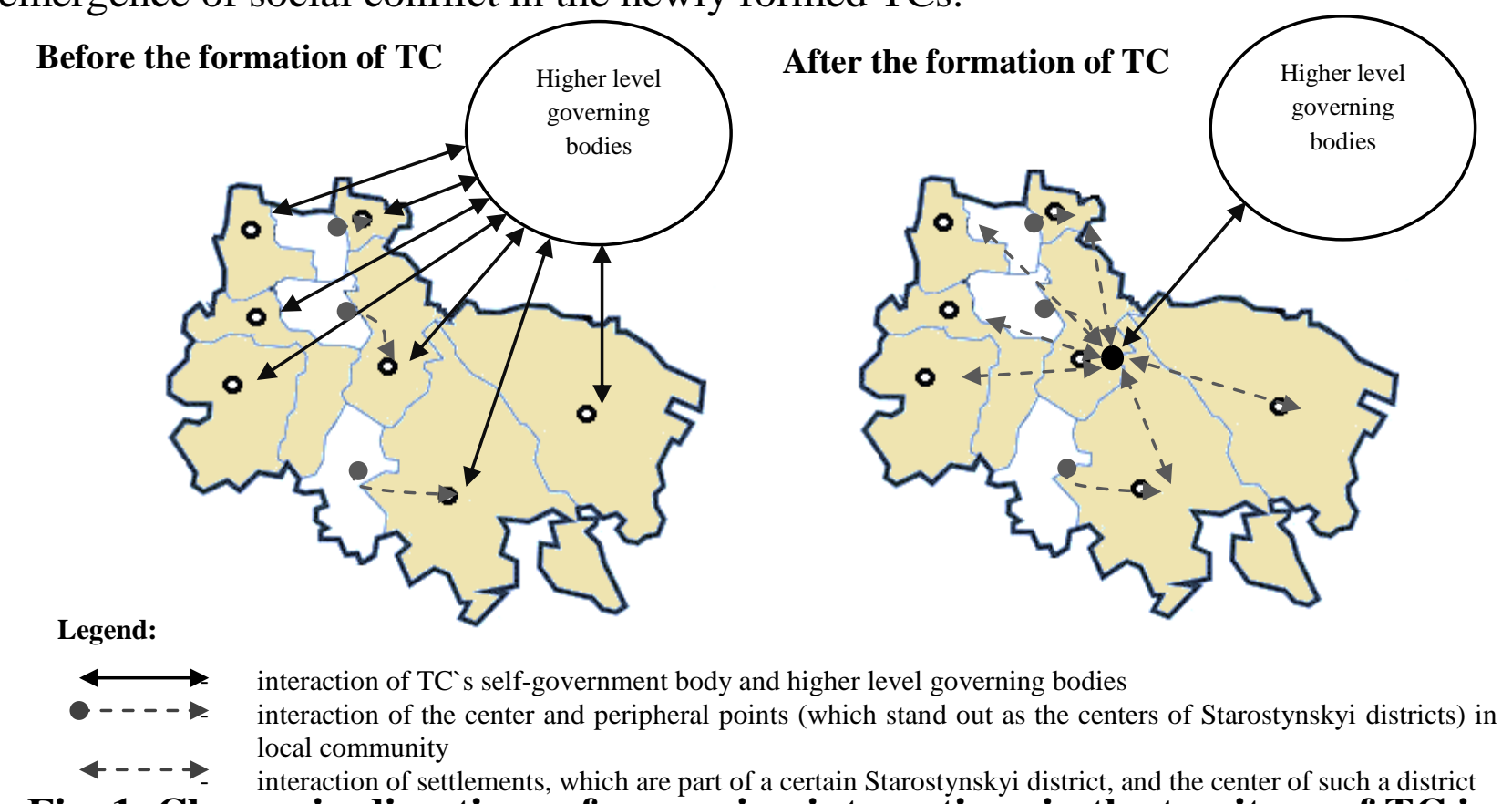

Fig. 1. Change in directions of governing interactions in the territory of TC in the context of administrative and financial decentralization

Source: formed by the authors.

In general, analyzing scientific and expert groundwork on the development of TC in Ukraine in the context of decentralization $[1 ; 2 ; 19 ; 20]$, one can state an almost complete lack of research on the socio-psychological climate in communities. At the same time, this issue requires special attention, because the "artificial" association of communities (which, despite the administrative-territorial certainty, inherent socio-psychological, historical, cultural, economic, organizational and functional characteristics, an emphasis on the community as a system with organized political, economic and social networks and common interests) requires a systematic

${ }^{1}$ For Lviv region - Order of the Cabinet of Ministers of Ukraine "On approval of the longterm plan for the formation of communities in the Lviv region" No. 624-r of May 27, 2020, available at: https://www.kmu.gov.ua/npas/pro-zatverdzhennya-perspektivnogo-planuformuvannya-teritorij-gromad-lvivskoyi-oblasti-i270520-624. 
approach to ensuring the cohesion of their residents and achieving self-identification of each member of the community by its part and assigns the main responsibility for the practical implementation of this task to local governing bodies. In this context, it is necessary to emphasize the lack of work of the relevant state authorities on the preparation (consultation, training and explanation) of self-government bodies of TCs on the formation of core-peripheral interactions in communities, their development as a single system and possible risks posed by the problem of isolation of individual cells.

Considering the different period of TC formation (communities have been formed during 2015-2020), the difference in the number of settlements, which have been united, features of the territorial location and its influence on the formation of core-peripheral interactions in society, as well as other factors of influence, it is worth specifying the object of research and carry out groupings of TC according to certain criteria.

Impact factors influencing the formation of core-peripheral interactions in the TC include:

1) type of TC (TC of town / township / village) - taking into account the type of settlement, which is the TC's administrative center, is important in the context of identifying the mutual influences of settlements in society. In particular, in TCs with a strong center (mainly town TCs belong to such communities), the risk of a monocentric model of development and distortion of territorial representation in local councils in favor of the center increases;

2) location in the region - the location of TC significantly affects the formation of core-peripheral interactions in the community. The location of TC in the suburban area is accompanied by an increase in migratory activity of residents of communities outside its borders and the formation of sustainable interactions at the level of "center-periphery" between the town and the adjacent territory, to which the territory of the TC belongs (which also significantly affects the core-peripheral interactions between settlements within the TC). In contrast, the external impact is less on TCs that are geographically distant from large town centers. Consideration of this factor can result in the identification of significant differences in the formation of coreperipheral interactions in the $\mathrm{TC}$;

3) characteristics of the TC composition - it is supposed to take into account the characteristics of TC in the context of the following indicators: number of settlements in the TC; population; remoteness of settlements of the community from its center.

Thus, the analysis of the formation and development of core-peripheral interactions at the TC level will be carried out on the basis of identifying TC groups according to the specified criteria and their diagnostics in the following areas:

- analysis of strategic documents of the local council of the TC on the development of core-peripheral interactions in society - taking into account the derivative nature of the formation of core-peripheral interactions in the TC, ensuring proper legal regulation of the development of the administrative-territorial formation as a whole and defining the role of each settlement in its composition is one of the 


\section{Agricultural and Resource Economics: International Scientific E-Journal http://are-journal.com}

key conditions for the integration of the community's population at the administrative, socio-economic and mental levels; the study of strategic documents for the development of TCs and methods for their development allows assessing the approach of local authorities to community development, understanding and implementation of the principles of representative democracy at the local level, as well as the development of public responsibility for local affairs;

- analysis of the governing structure of the local council of the TC, representation of peripheral communities, development of the institution of eldership, compliance of the composition and structure of the governing body with the goals of community development - taking into account the peculiarities of TC formation, in particular, the existence of communities in which the population is proportionally distributed between settlements, and communities with a pronounced dominance of the administrative center (where most of the population of the TC lives, the financial and governing potential of the territory is concentrated), attention should be focused on the issue of representation of residents of peripheral settlements in the TC governing apparatus and their involvement in the decision-making process;

- analysis of budget support for infrastructure development in TC - the state, development and location of social and transport infrastructure is especially important, as achieving appropriate infrastructure development in the community allows local governments to ensure equal access to quality public services;

- study of employment opportunities in the community - one of the key conditions for the development of TC towards the formation of stable core-peripheral relationships in the community is the development of business environment, which implies, among other things, the activities of the local government body to realize the possibilities of official employment of the TC population. Among the key areas of stimulating the employment of the community population on its territory, it is first of all worth highlighting the following: attraction of entrepreneurs, investors, cooperation and creation of favorable conditions for the development of business entities in the community; community human capital development; cooperation with employment centers, other institutions and organizations in this area.

The method of diagnostics of the formation of core-peripheral interactions in TC was tested on the communities of one of the regions of Ukraine - Lviv region. Given the unformed statistical base of TC in Ukraine and Lviv region in particular, for the analysis of core-peripheral interactions, territorial communities were selected due to different characteristics (year of formation, type of community (town / township / village), community composition, location in the region) to which requests were sent so that to obtain the necessary information, and a survey of local council head was conducted as well ${ }^{2}$.

${ }^{2}$ The survey of heads of councils of territorial communities of Lviv region was conducted by M.I. Dolishny Institute of Regional Researsh of the National Academy of Sciences of Ukraine in June-August 2020 and included 24 questions on the development of central-peripheral interactions in their communities. 


\section{Agricultural and Resource Economics: International Scientific E-Journal http://are-journal.com}

Given the peculiarities of the formation of territorial communities, an important issue is to determine the structure and composition of such communities (Fig. 2, Fig. 3).

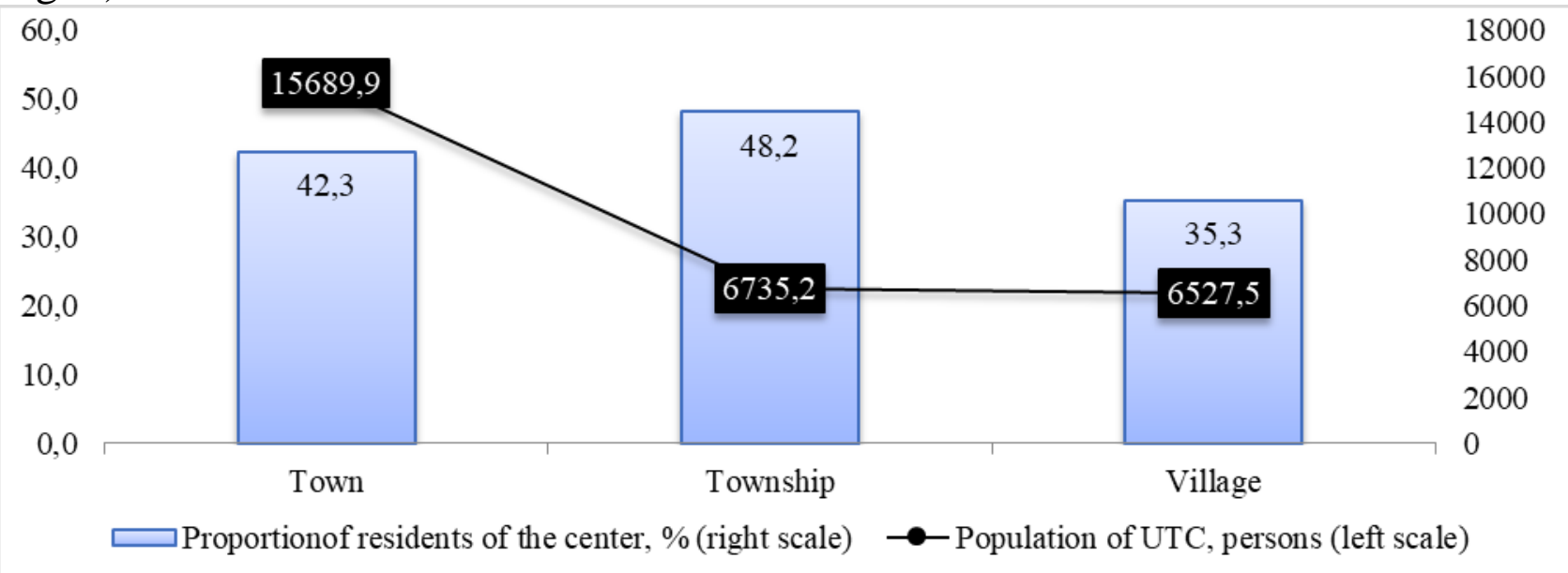

Fig. 2. Average population of TCs of Lviv region in terms of community type (town / township / village), 2020

Source: compiled on the basis of data from the United Communities Portal of Ukraine Gromada.Info [23].

The formation of town TCs in the region was accompanied by the coverage of a large territory (on average $225.1 \mathrm{sq} . \mathrm{km}$ ) and a larger number of local councils (on average 6.9 councils), compared to TCs was formed around villages and townships, which in the context of voluntary enlargement can be explained by the desire to unite settlements in peripheral areas in towns around Lviv in order to build up their own financial and economic potential and ensure the socio-economic development of the territory. Therefore, the average population of the town TCs in the region is twice the average of TCs in the Lviv region and is 15689.9 people, and awerage $42.3 \%$ of its population lives in the center of the town community. In the context of the town TCs of the region, it can be seen that the largest proportion of the center residents $(58.4 \%)$ is in Sudova Vyshnia TC, the smallest $(24.1 \%)$ - in Bibrka TC.

The situation is different in the village and township TCs. The consolidated communities formed around villages and townships include fewer settlements compared to urban communities. The average number of residents in the township and village TCs is similar and fluctuates around 6,500-6,700 people. At the same time, the analysis of the residents' proportion of the settlement - the center as part of the communities' population in the group of village TCs of the Lviv region is the highest and amounts to $48.2 \%$.

The group of township TCs is represented by 10 administrative-territorial entities, in $1 / 2$ of which the share of inhabitants of the center is higher than $50.0 \%$, and in Nyzhankovychi and Dubliany communities, it is $72.4 \%$ and $60.2 \%$, respectively. The peculiarity of these TCs is that they are formed of $2-3$ local councils and in terms of population belong to small communities with less than 3.0 thousand people. From January 1, 2021, these communities will be part of more powerful TC, which, in our opinion, indicates their inability to ensure the economic 


\section{Agricultural and Resource Economics: International Scientific E-Journal http://are-journal.com}

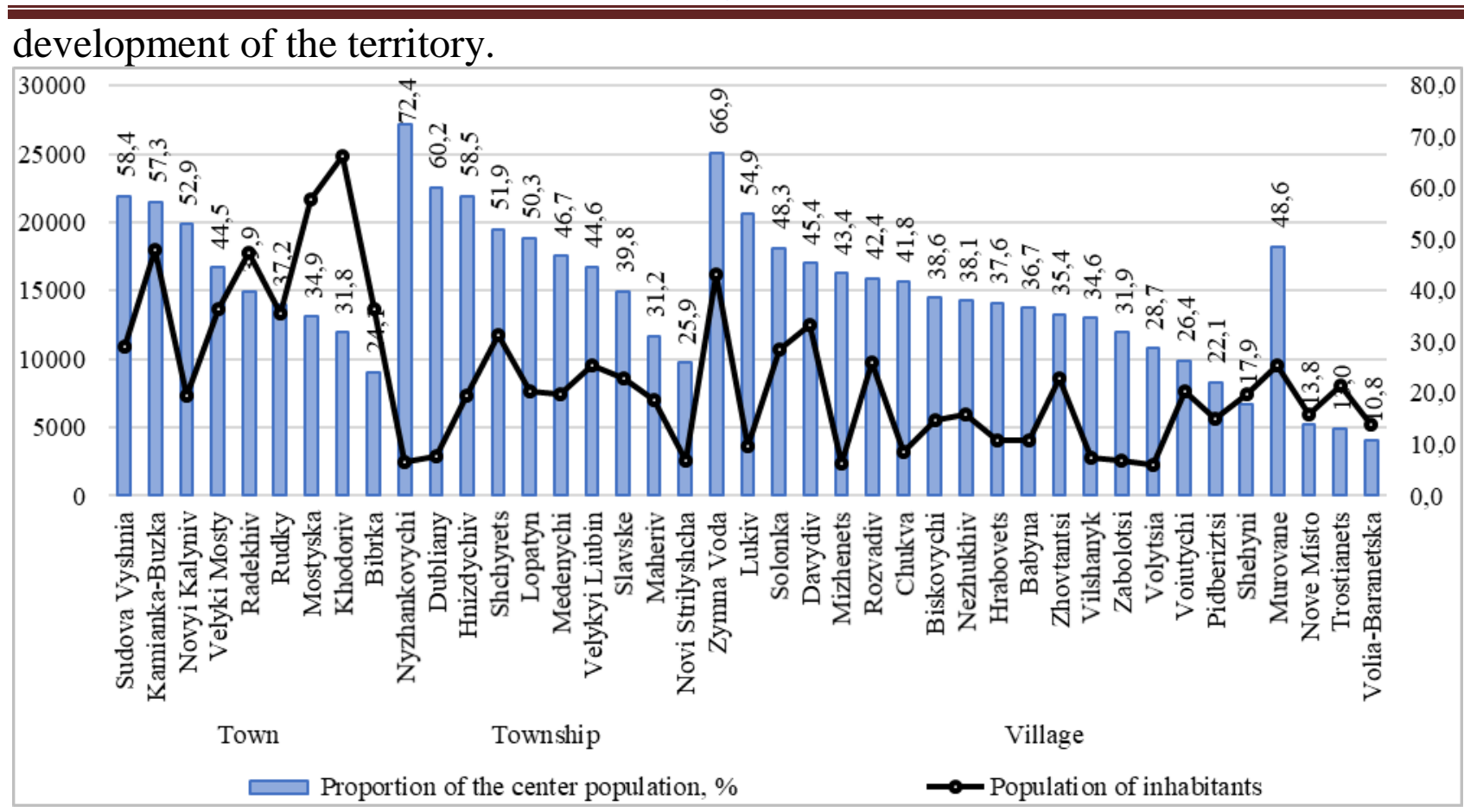

Fig. 3. Population of TCs of Lviv region in terms of community type (town / township / village), 2020

Source: compiled on the basis of data from the United Communities Portal of Ukraine Gromada.Info [23].

Regarding village TCs, in most communities the share of the center's residents is less than $40.0 \%$. Exceptions are the communities formed around the city of Lviv, Zymna Voda (66.9\%), Solonka (48.3\%), Davydiv (45.4\%), where the highest indicator of population concentration is in the center. In addition, the peculiarity of these TCs is that the settlement, which is the center of the community, borders on Lviv (regional center), which, in our opinion, gives it additional benefits.

Taking into account the chosen research methodology and the results of the survey of heads of local TC councils, 13 territorial communities of different types were selected for analysis, in particular: 1) by TC type: 4 town (Kamyanka-Buzka, Radekhivska, Rudkivska, Khodorivska), 1 township (Medenytska) and 8 village (Voyutytska, Grabovetska, Zhovtanetska, Zabolottsivska, Murovanska, Lukivska, Pidberiztsivska, Solonkivska); 2) by location in the region - TC, which directly borders on the city - regional center (Murovanska, Pidberiztsivska, Solonkivska), and TC, which are geographically distant from large cities. In addition, all communities differ in other characteristics (number of settlements in the TC; population; remoteness of settlements from the community center).

1. Analysis of strategic documents of the local council of the TC on the development of core-peripheral interactions.

Analysis of the state of the development of strategic documents for individual communities of the Lviv region made it possible to establish that development strategies have been elaborated only by half of the TCs, in some TCs strategies are at the development stage.

Most of the strategies were developed using the method of "complicity", that is, 
with the involvement of the local government, experts and community members with the identification of leaders of local communities and businesses on the basis of a long-term partnership (strategies of Zabolotsi, Kamianka-Buzka, Rudky and Solonka TCs; Zhovtantsi TC officials also indicate strategies by the method of "complicity").

It is worth noting that international experts were involved in the process of strategizing the development in each of these communities. Analyzing the listed strategic documents, we should note their high level, since they: 1) unite all participants in the development (after all, they were developed with the involvement of representatives of all interested groups in the community and external experts); 2) correspond to national and regional strategic documents; 3) contain a fundamental diagnostic and analytical part and are formed using the data accumulated in the process of questioning residents, that is, taking into account the opinions and views of the residents of the community on the development of the territory, on the basis of which the directions of activity are determined.

In individual communities, strategies are developed using other methods, in particular, expert and advisory that is based on the work of experts and their full interaction with community members, but does not provide for sufficient participation in the process of the local government, and then is accompanied by the risk of the strategy being "disconnected" from real opportunities for community management.

Despite the complexity of most of the developed strategies and focusing not only on the development of a strong center, but also on the potential of all settlements within the TC, only three of the thirteen analyzed strategies identified and substantiated the goal of communicating with the community and involving the public in land management. If the issue of business development and investment is identified as one of the priorities for the development of all TCs, which have developed strategies that are clear and meet the need to achieve community selfsufficiency, the development of core-peripheral interactions today occurs only in the context of ensuring progress of community settlements and increasing the level of social services provided to residents of the settlements.

2. Analysis of the management structure of the local council of the TC, representation of peripheral communities, development of the institute of monitor, compliance of the composition and structure of the governing body with the goals of community development.

Speaking about the development of TC in terms of administrative decentralization, one can notice a certain dissonance, since the formation of capable TC requires an economically developed center (which is mainly a town), and this is mainly accompanied by a distortion of the territorial representation of the community in the local council in its advantage and also results in configuration of TC, where one settlement is significantly larger than the others.

First of all, the number of deputies-representatives of each locality directly correlates with the number of voters in such a locality, and, accordingly, with the 
population. Thus, the analysis of the composition of the deputy corps in the TC of the Lviv region (Fig. 4) makes it possible to notice the following trends:

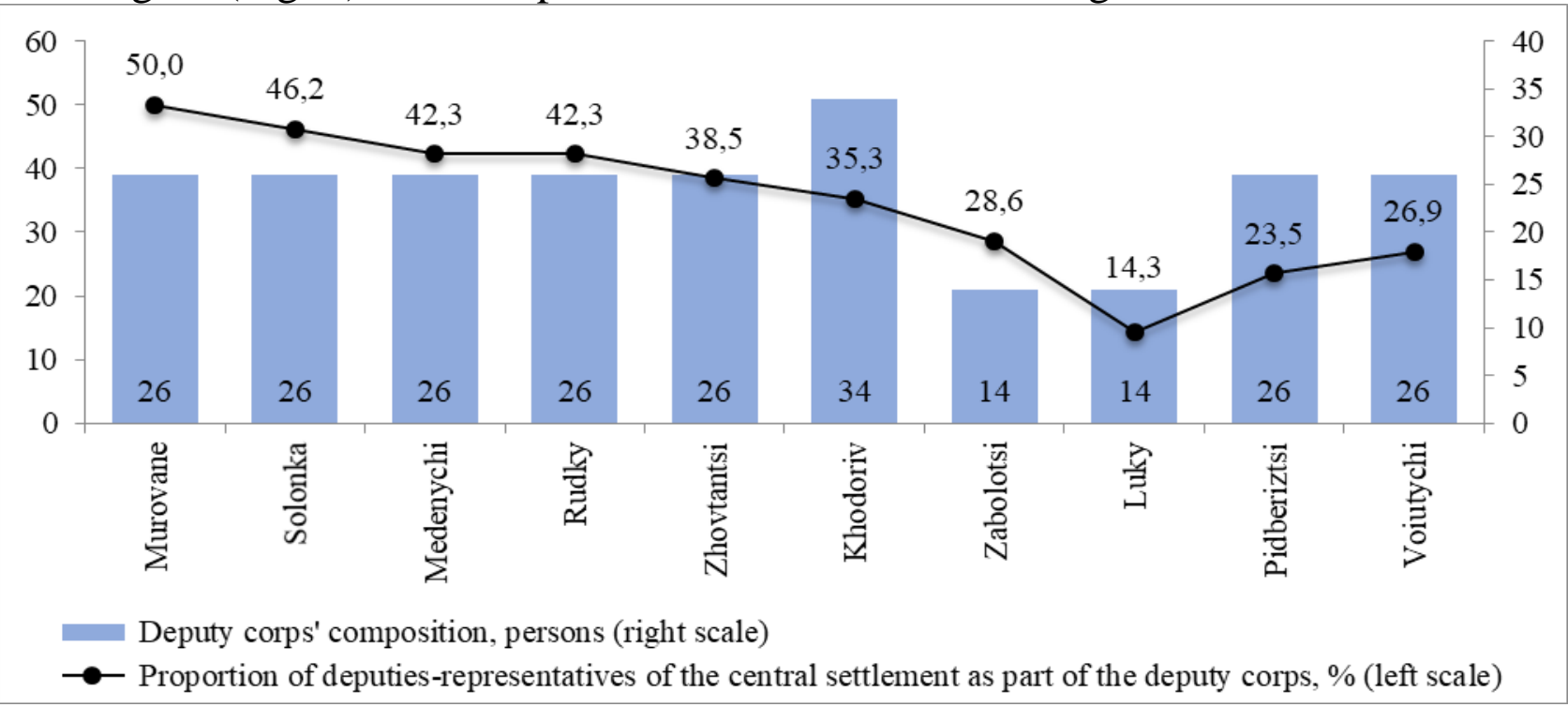

Fig. 4. Number of deputies of town, township, village councils of TC of Lviv region, 2020

Source: compiled on the basis of a questionnaire of the chairmen of the TCs of the Lviv region.

1) a high proportion of deputies-representatives of the community-center in the village TCs formed around the regional center (in Murovane $(50.0 \%$ ) and Solonka $(46.2 \%) \mathrm{TCs})$, where central settlements are significantly dominated by others in size (number of inhabitants). In these communities, a monocentric model of government is being formed, since half of the deputies represent one locality.

2) proportion of deputies-representatives of the central settlement in the town TCs is noticeably lower (for example, in Khodoriv TC $-35.3 \%$, in Rudky $-42.3 \%$ ). Town communities include a large number of settlements (for example, the analyzed town TCs of Lviv region includes an average of 24 settlements), which results in a certain "dispersion" of representatives-deputies and, accordingly, the concentration of deputy representation in the town ( that is represented by 12 deputies in Khodoriv TC); consequently, in such communities there is a risk of the deputies' failure from peripheral points to influence the agenda and voting in the council that leads to significant complications for the deputy to properly represent the interests of his own voters and protect them;

3) communities with a symmetrical configuration are characterized by polycentrism in governance, since the number of deputies-representatives of each district does not differ significantly. These communities include Lukiv (14.3\% of the center deputies), Zabolotsi (28.6\%), Volytsia (26.9\%), Pidberiztsi (23.5\%).

At the same time, the executive committee has a significant influence on the development of TC and the formation of core-peripheral interactions of a socioeconomic nature in the community. As a collegial body of general competence, the executive committee heads the system of executive bodies of the local council and directs, coordinates and controls their activities. Analyzing the quantitative and 
personal composition of the executive committees of local councils of TC, it should be noted: if the personal composition of the executive committee is justified to some extent (in particular, the heads are members of the executive committee), the quantitative is not legally established. In the context of the formation and development of TC, this resulted in the formation of executive committees of the TC councils in terms of the number of deputies.

Analyzing the personal composition of executive committees of the TC local councils of the Lviv region (Fig. 5), two types of composition can be distinguished: administrative and bureaucratic (represented by local council officials, monitors, sometimes heads of public utility companies, educational institutions, health care) (Hrabovets, Solonka, Pidberiztsi TC) and mixed (in addition to the above, the executive committee includes public activists, representatives of public organizations, local entrepreneurs and other community representatives) (Zabolotsi, Lukiv, Kamianka-Buzka, Rudky, Radekhiv and other TCs).

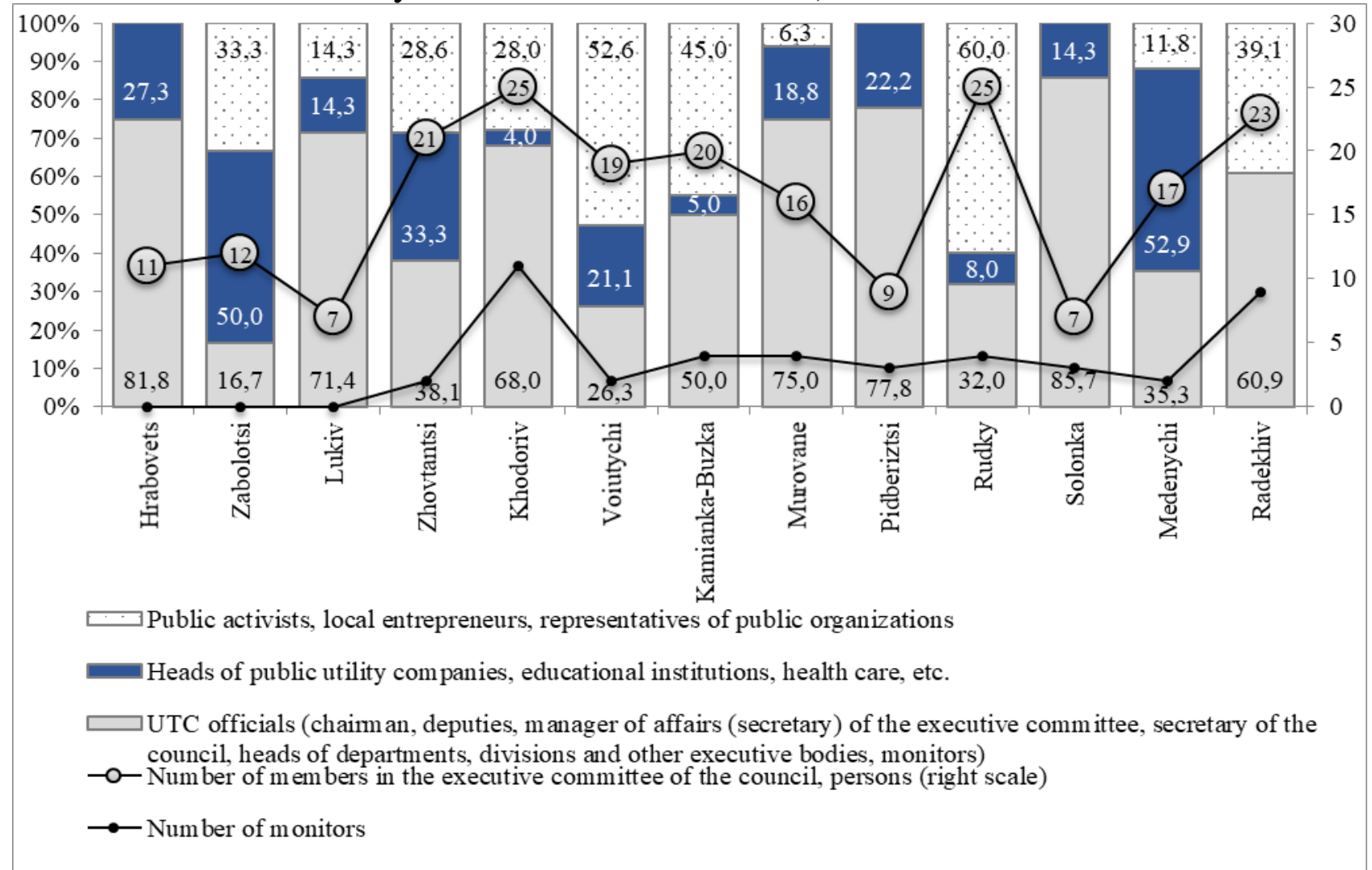

Fig. 5. Structure of executive committees of town, township, village councils of TC of Lviv region, 2020

Source: compiled on the basis of a questionnaire of the chairmen of the TCs of the Lviv region.

In the context of analyzing the role of the executive committee in the formation of effective core-peripheral interactions in the community, it is worth noting the following: only in two of the 13 TCs under consideration, the number of monitors in the executive committee exceeds $40 \%$ of members (Khodoriv and Solonka), which makes it possible for representatives of peripheral settlements to influence making management decisions and choosing directions for the development of TC. In all 
other TCs, there may be a situation where the voice of the headman as a direct representative of the peripheral district will not have "weight" in decision-making in the executive committees.

3. Analysis of budget support for infrastructure development in TC.

The study of the problem of observance of the interests of peripheral settlements in the context of the implementation of infrastructure projects was carried out by comparing the proportion of local budget revenues accumulated in the territory of each monitor county and the share of funds from the budget, in the form of capital expenditures, are directed to the development of each monitor (starostynksyi) county (Fig. 6). The analysis was carried out on the basis of a comparison of data on the accumulation and distribution of funds from local budgets of five TCs of the Lviv region, which made it possible to draw certain conclusions.

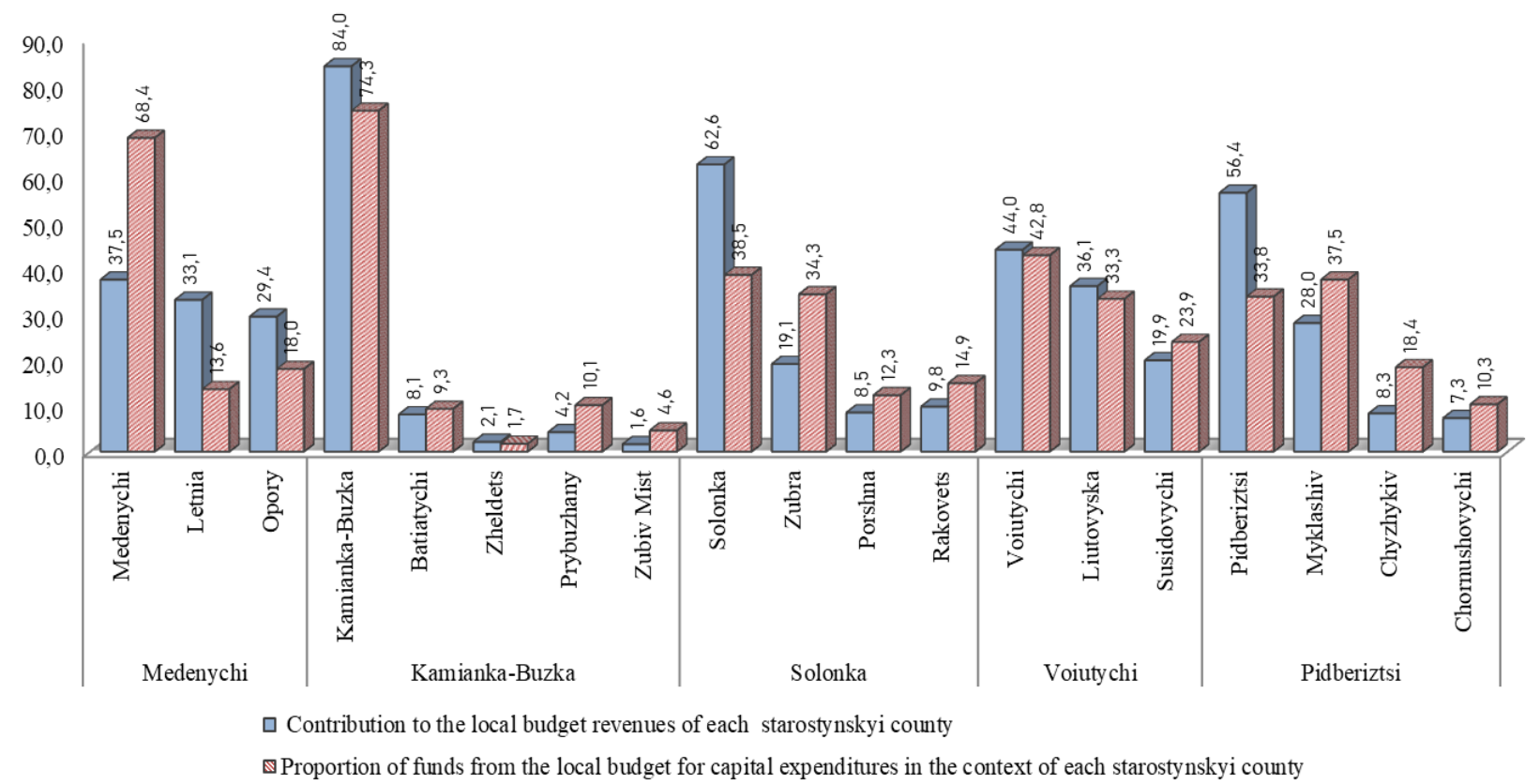

Fig. 6. Proportion of revenues accumulated in the local budget and capital expenditures from the budget in the context of the TC monitor counties of the Lviv region, 2018-2019, \%

Source: compiled on the basis of a questionnaire of the chairmen of the TCs of the Lviv region.

Significant disparities regadring accumulated and distributed funds are observed in the Kamianka-Buzka TC. This is a town community, and it is formed with the center in the town of Kamianka-Buzka, which is at the same time a district center, which makes it possible to assert a significantly higher level of socio-economic development of the center. Accordingly, $84.0 \%$ of the funds accumulated on the territory of TC to the local budget were collected in the center of the community. At the same time, the analysis of the distribution of capital expenditures in the context of monitor counties indicates a unilateral redistribution of financial resources in favor of the town $(74.3 \%)$. In addition, the influence of the territorial remoteness of the peripheral district from the center is noticeable in the distribution of financial resources from the local budget. 


\section{Agricultural and Resource Economics: International Scientific E-Journal}

http://are-journal.com

Disproportions of accumulation and distribution of financial resources of the local budget are observed in the Medenychi village TC. However, unlike the community of Kamianka-Buzka, where monitor counties were still allocated a larger proportion of capital expenditures than the accumulated one, the peripheral counties of Medenychi TC "gave" more than "received". $68.4 \%$ of capital expenditures made from the local budget related to projects being implemented in the territory of the community center (considering that $37.5 \%$ of the own local budget were accumulated in Medenychi).

Another situation is observed in Solonka, Pidberiztsi and Voiutychi TCs, where the accumulated resources are distributed in favor of the peripheral monitor counties. At the same time, in Solonka TC, where more than $62.0 \%$ of income is accumulated on the territory of the center, the main distribution of funds for capital expenditures took place between the center and Zubra monitor county (close to the center), that border the regional center and through which passes the ring road of the city of Lviv ( $72.8 \%$ of capital expenditures).

Thus, the analysis of the distribution of financial resources through capital expenditures makes it possible to notice the following trends:

1) redistribution of budgetary funds in favor of the community center (after all, in each of the considered TCs, relatively more is directed towards the development of the center);

2) influence of the factor of territorial remoteness from the center of the community on the distribution of funds (large capital expenditures are directed to the development of monitor counties located close to the center);

3 ) influence of the factor of passing through the territory of monitor county that is important for the community highway.

4. Research of employment opportunities in the community.

Analyzing the formation of core-peripheral interactions in TC, special attention should be paid to the issue of employment because the lack of opportunities and prospects for a job search stimulates the centrifugal processes that accompany the outflow of population and increases the likelihood of conflict situations [24].

During interviewing the chairmen of the TCs of the Lviv region regarding the peculiarities of employment of the population of their community (Table 1), it was established:

1) all representatives of local self-government bodies of $\mathrm{TC}$ define the community as a territory in which most of the population is employed. In addition, since the formation of $\mathrm{TC}$ in the Lviv region, there has been an increase in the number of jobs in most communities. Among the leaders: Murovane and Pidberiztsi TCs (356 and 150 new work places, respectively), which are first of all attractive for investors and new enterprises due to their territorial proximity to the regional center and passing through the territory of highways; Kamianka-Buzka TC (256 new work places) with an economically developed and logistically attractive center; Zabolotsi TC (210 new work places), which, despite its small size and formation on the basis of two local councils, territorial remoteness from town centers, 
stimulated the involvement of its own population in the development of family farms and created conditions for the registration and development of new enterprises in the community (power plants, poultry farms).

Table 1

\section{Territorial distribution of workplaces of the population of TCs of Lviv region}

\begin{tabular}{|l|c|c|c|c|c|c|c|}
\hline \multirow{2}{*}{ Indicators } & \multicolumn{7}{|c|}{ Local population is employed: } \\
\cline { 2 - 8 } & $\begin{array}{c}\text { within } \\
\text { the TC }\end{array}$ & $\begin{array}{c}\text { in the } \\
\text { town- } \\
\text { regional } \\
\text { center }\end{array}$ & $\begin{array}{c}\text { in the } \\
\text { nearby } \\
\text { town }\end{array}$ & $\begin{array}{c}\text { within } \\
\text { the } \\
\text { district }\end{array}$ & $\begin{array}{c}\text { within } \\
\text { the } \\
\text { region }\end{array}$ & $\begin{array}{c}\text { in other } \\
\text { regions } \\
\text { of } \\
\text { Ukraine }\end{array}$ & abroad \\
\hline Zabolotsi & + & - & - & + & + & - & + \\
\hline Lukiv & + & - & - & - & + & - & + \\
\hline Zhovtantsi & + & - & - & - & + & - & + \\
\hline Khodoriv & + & - & - & - & + & - & + \\
\hline Voiutychi & + & - & $+($ Sambir) & - & - & - & + \\
\hline Kamianka-Buzka & + & + & - & + & - & - & + \\
\hline Murovane & + & + & - & - & - & - & + \\
\hline Pidberiztsi & + & + & - & + & - & - & - \\
\hline Rudky & + & - & - & - & + & - & + \\
\hline Solonka & + & + & - & + & - & - & - \\
\hline Medenychi & + & - & + & + & - & - & - \\
\hline Radekhiv & + & - & - & - & + & - & + \\
\hline
\end{tabular}

Note: + TC population is aimed at employment.

- TC population is not aimed at employment.

Source: compiled on the basis of a questionnaire of the TC chairmen of the Lviv region.

2) significant dependence of the development of the labor market in the TC on the proximity to developed towns - centers of economic growth.

In general, the flow of people in Lviv is $7 \%$ formed by residents of the region in the process of commuting (based on trips to work), that is, on average, 152 thousand people come to Lviv within one day, while $50.1 \%$ of commuters are residents of settlements located at a distance of $15 \mathrm{~km}$ from Lviv, and $84.1 \%$ are residents of communities within a radius of $40 \mathrm{~km}$ around the regional center (Fig. 7) [25]. It makes possible to establish that Lviv significantly affects the formation of labor markets in communities within a radius of up to $40 \mathrm{~km}$ (Solonka, Zymna Voda, Pidberiztsi, Murovane and Davydiv TCs, Trostianets, Shchyrets, Velykyi Liubin, Zhovtantsi, Kamianka-Buzka and Bibrka TCs).

Mentioned above is confirmed by the results obtained owing to questioning of the chairmen of the TCs. So, communities located at a distance of up to $15 \mathrm{~km}$ from the regional center (Solonka, Pidberiztsi, Murovane OTCs) clearly indicate that Lviv is a key center of employment for their population. This was emphasized by the chairman of Kamianka-Buzka TC, which is located in a 40-kilometer zone around Lviv.

On the other hand, Medenychi and Voiutychi TCs point to nearby towns as employment centers for their populations. 


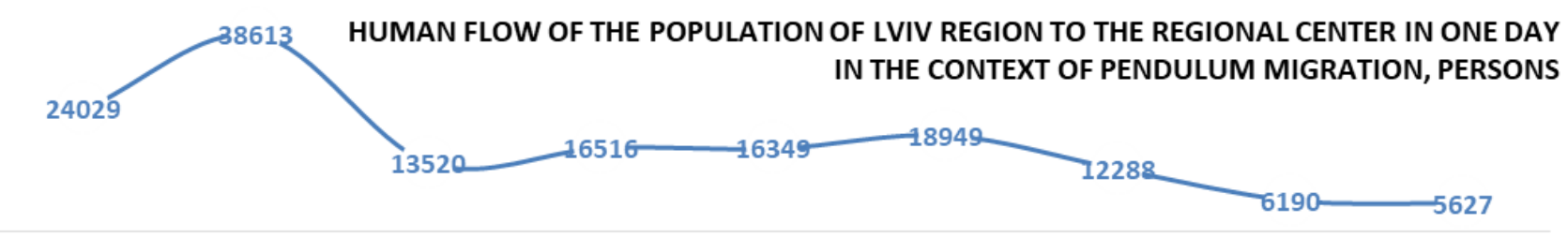

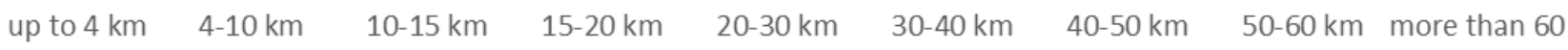

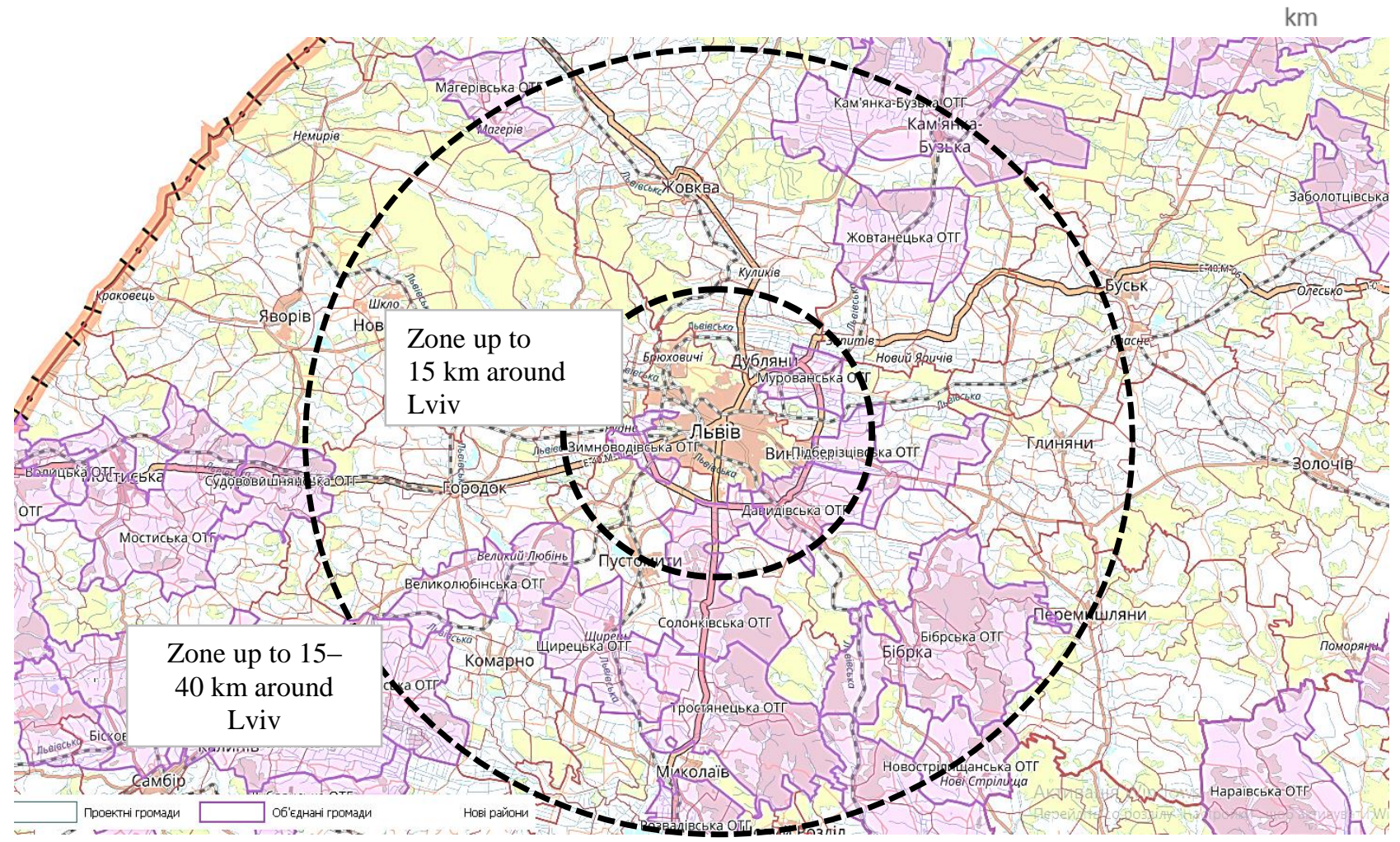

Fig. 7. Zones of influence of Lviv city on the formation of labor markets in the TC of the Lviv region, 2018

Source: compiled on the basis of the results of a joint study of the Lviv City Council and "Vodafone Ukraine" company.

3) problem of leaving community residents abroad in search of work remains topical and unresolved, which was emphasized by 8 chairmen of the TCs out of 12 respondents. Only the communities' heads directly bordering Lviv city did not focus on this aspect.

Conclusions. Thus, in the context of the study of the formation of coreperipheral interactions in the TCs of the Lviv region, carried out on the basis of the analysis of statistical information, budget indicators and thanks to the data obtained by interviewing heads of communities, the following conclusions can be drawn.

1. As a result of the enlargement of local councils, TCs were formed in the region, which can conditionally be typified into communities of mono- (communities with a pronounced economically and socially developed center in comparison with other settlements of TCs, such as town TCs) and polycentric type (communities that are formed by combining settlements of the same type, equal in economic and social development (village and township)), which also leads to the peculiarities of the formation of core-peripheral interactions, in particular the existing problem of the 
disparity distribution of the territorial representation of settlements in local government bodies of town communities, and therefore, both the impossibility of effective influence of the population of the periphery on the community development, and the low level of the ability of most polycentric-type communities to ensure their own economic development. This is indicated by the decision of the Cabinet of Ministers of Ukraine to join large communities or to enlarge 15 TCs in the Lviv region. This process can be characterized as an artificial (managerial) suspension of the formation of core-peripheral interactions in communities that may result in an increased risk of rejection by members of the disbanded TCs of the new government and the emergence of social conflict in the newly formed TCs.

2. Location of the community has a significant impact on the formation of coreperipheral interactions in the TC of the region. Communities that directly border Lviv city are characterized by overwhelming employment of the able-bodied population, use of social services, leisure activities in the city; TC settlements perform a "sleeping" function for many residents. This significantly complicates the formation of core-peripheral interactions and can result in the development of relations of an administrative nature (when residents of peripheral settlements turn to the center only to receive administrative services). At the same time, such communities have better initial conditions for economic development of the territory, attraction of enterprises and investment resources, development of the service sector, as indicated by the relatively high financial viability of the polycentric type of TC around Lviv city.

3. Despite these aspects, the development of core-peripheral interactions in the TC in the context of their formation is, first of all, the issue of effective management of the existing potential, ensuring the participation of residents in the development of their own community and the formation of relationships community - local selfgovernment body. Indeed, in the context of the formation of stable core-peripheral interactions of a socio-economic nature, the provision of mental perception by the inhabitants of the community by its part takes place.

A promising area of further research is the development of scientific and methodological recommendations to avoid / reduce the risks of social, economic, managerial isolation of the TC territories formed as a result of administrativeterritorial reform.

\section{References}

1. Shvets, T., Plotnikova, M., Prysiazhniuk, O. and Kostyuk, L. (2019), Administrative and innovational approaches in socialand business capital formation in the contextof decentralization. Agricultural and Resource Economics, vol. 5, no. 3, pp. 152-170. https://doi.org/10.22004/ag.econ.293991.

2. Storonyanska, I. and Benovska, L. (2017), Risks of administrative and financial decentralisation: theoretical hypotheses and empirical assessment. Economic Annals-XXI, vol. 166, is. 7-8, pp. 76-79. https://doi.org/10.21003/ea.V166-15.

3. Hrynchyshyn, I., Bil, M., Popadynets, N., Patytska, K., Leshchuh, I., Panukhnyk, O. (2019), Scientific-methodical foundations of estimation of territorial 
communities' endogenous capacity in Ukraine in conditions of decentralization. Advances in Economics, Business and Management Research, vol. 95, pp. 314-319.

4. Rhodes, M. J., Epstein, R. and Börzel, T. A. (2019), Introduction: peripheries in competition? Political and economic development in the EU. West European Politics, vol. 42, is. 5, pp. 927-940. https://doi.org/10.1080/01402382.2019.1609195.

5. Börzel, T. A. and Langbein, J. (2019). Core-periphery disparities in Europe: is there a link between political and economic divergence? West European Politics, vol. 42, is. 5, hp. 941-964. https://doi.org/10.1080/01402382.2018.1558534.

6. Uwazie, I. U., Igwemma, A. A. and Ukah, F. I. (2015), Contributions of Andre Gunder Frank to the Theory of Development and Underdevelopment: Implications on Nigeria's Development Situation. Journal of Economics and Sustainable Development, vol. 6, no. 18, pp. 27-38.

7. Krugman, P. (1998), What's new about the new economic geography? Oxford Review of Economic Policy, vol. 14, is. 2, pp. 7-17. https://doi.org/10.1093/oxrep/14.2.7.

8. Ascani A., Crescenzi, R. and Iammarino, S. (2012), New economic geography and economic integration: a review search. Search working paper WP01/02. London School of Economics and Political Science, London, UK, available at: http://www.ub.edu/searchproject/wp-content/uploads/2012/02/WP1.2.pdf.

9. Caraveli, H. (2017), The dynamics of the EU core-periphery division: Eastern vs. Southern periphery - a comparative analysis from a new economic geography perspective in Core-Periphery Patterns Across the European Union, ed. G. C. Pascariu and M. A. P. D. S. Duarte, Emerald Publishing Limited, Bingley, UK. https://doi.org/10.1108/978-1-78714-495-820171001.

10. Naumann, M. and Fischer-Tahir, A. eds. (2013), Peripheralization. The making of spatial dependencies and social injustice. VS Verlag für Sozialwissenschaften, Germany. https://doi.org/10.1007/978-3-531-19018-1.

11. Schulz, S. (2020), Ambitious or ambiguous? The implications of smart specialisation for core-periphery relations in Estonia and Slovakia. Baltic Journal of European Studies, vol. 9, is. 4, pp. 49-71. https://doi.org/10.1515/bjes-2019-0037.

12. Magerman, G., De Bruyne, K., Van Hove, J. (2020), Pecking order and coreperiphery in international trade. Review of International Economics, vol. 28, is. 4, pp. 1113-1141. https://doi.org/10.1111/roie.12483.

13. Cohendet, P., Grandadam, D., Mehouachi, C. and Simon, L. (2018), The local, the global and the industry common: the case of the video game industry. Journal of Economic Geography, vol. 18, is. 5, pp. 1045-1068. https://doi.org/10.1093/jeg/lby040.

14. Bernt, M. and Colini, L. (2013), Exclusion, marginalization and peripheralization conceptual concerns in the study of urban inequalities. Working Paper no. 49. Leibniz Institute for Regional Development and Structural Planning, Erkner, Germany.

15. Nordlund, C. (2018), Power-relational core-periphery structures: peripheral 
dependency and core dominance in binary and valued networks. Network Science, vol. 6, is. 3, pp. 348-369. https://doi.org/10.1017/nws.2018.15.

16. Draçi, B., Çaro, D. and Nikolli, P. (2014), Center - periphery urban territorial dynamics: the case of Durrës municipality - Albania. Mediterranean Journal of Social Sciences, vol. 5, no. 9, pp. 552-557. https://doi.org/10.5901/mjss.2014.v5n9p552.

17. Kubeš, J. and Chvojková, A. (2020), Back to peripheries based on remoteness. Human capital in the peripheral municipalities of South Bohemia. Journal of Rural Studies, vol. 79, pp. 116-124. https://doi.org/10.1016/j.jrurstud.2020.08.045.

18. Pociute-Sereikiene, G. and Kriaučiunas, E. (2018), The development of rural peripheral areas in Lithuania: the challenges of socio-spatial transition. European Countryside, vol. 10, is. 3, pp. 498-515. https://doi.org/10.2478/euco-2018-0028.

19. Pylypenko, I. (2014), The general characteristics of the methods in socialgeographic analy sis of the "center-periphery» system. Human Geography Journal, vol. 17, no. 2, pp. 47-50. https://doi.org/10.26565/2076-1333-2014-17-08.

20. Pidgrushny, G. P. and Denisenko, O. O. (2013), Kyiv and surrounding territory in the center - peripherial interaction. Ukrainian Geographical Journal, vol. 1, pp. 27-34. https://doi.org/10.15407/ugz2013.01.027.

21. Melnik, M. I. (2016), Metropoliyni funktsiyi velykykh mist Ukrayiny: potentsial rozvytku ta perspektyvy realizatsiyi [Metropolian functions of large cities of Ukraine: development potential and prospects of implementation], NAS of Ukraine; SI Dolishny Institute for Regional Studies of the National Academy of Sciences of Ukraine, Lviv, Ukraine.

22. Mezentsev, K. V., Pidgrushny, G. P. and Mezentseva, N. I. (2014), Rehional'nyy rozvytok $v$ Ukrayini: suspil'no-prostorova nerivnist' $i$ polyaryzatsiya [Regional development in Ukraine: socio-spatial inequality and polarization], Print Service, Kyiv, Ukraine.

23. Portal of united communities of Ukraine Gromada.Info (2020), available at: https://gromada.info/region.

24. Davis, J. B. (2019), Economics and economic methodology in a coreperiphery economic world. Brazilian Journal of Political Economy, vol. 39, no. 3. https://doi.org/10.1590/0101-35172019-3004.

25. Official site of the Lviv City Council (2020), Lviv City Council together with Vodafone Ukraine conducted a large-scale study to develop the city's transport model, available at: https://city-adm.lviv.ua/news/city/lviv-changes/251171-lvivskamiska-rada-spilno-z-kompaniieiu-vodafone-ukraina-provely-masshtabnedoslidzhennia-dlia-rozvytku-transportnoi-modeli-mista. 
How to cite this article? Як цитувати цю статтю?

Стиль-ДСТУ:

Storonyanska I., Patytska K., Hrynchyshyn I., Chemerys V. Spatial disproportions in development of territorial community under conditions of administrative and financial decentralization. Agricultural and Resource Economics. 2020. Vol. 6. No. 4. Pp. 43-62. URL: https://are-journal.com.

Style - Harvard:

Storonyanska, I., Patytska, K., Hrynchyshyn, I. and Chemerys, V. (2020), Spatial disproportions in development of territorial community under conditions of administrative and financial decentralization. Agricultural and Resource Economics, vol. 6, no. 4, pp. 43-62, available at: https://are-journal.com. 